\title{
PROFIL KOMPETENSI PEDAGOGIK GURU TAMAN KANAK-KANAK TERSERTIFIKASI DI KECAMATAN CICALENGKA KABUPATEN BANDUNG
}

\author{
Eka Fuji Lestari ${ }^{1}$ \\ Robandi Roni M. A. ${ }^{2}$ \\ Endah Silawati ${ }^{3}$ \\ Jurusan Pendidikan Guru Pendidikan Anak Usia Dini Fakultas Ilmu \\ Pendidikan Universitas Pendidikan Indonesia eka.fujilestari(q)yahoo.com \\ ABSTRAK
}

\begin{abstract}
Abstrak Profil Kompetensi Pedagogik Guru Taman Kanak-kanak Tersertifikasi Kabupaten Bandung. Kompetensi Pedagogik merupakan kompetensi yang penting dalam pembelajaran. Dengan adanya sertifikasi, pemerintah berharap bisa meningkatkan kompetensi ini sehingga tujuan pembelajaran bisa tercapai. Namun pada kenyataannya, masih ada guru tersertifikasi yang belum memiliki kompetensi pedagogik yang baik. Kecamatan Cicalengka memiliki persentase terbesar keempat untuk guru TK tersertifikasi seKabupaten Bandung. Oleh karena itu penulis tertarik untuk melakukan penelitian mengenai profil kompetensi pedagogik guru TK yang dilaksanakan di Kecamatan Cicalengka Kabupaten Bandung dengan responden sebanyak 33 guru yang semuanya wanita. Penelitian ini bertujuan untuk memperoleh gambaran mengenai kompetensi pedagogik. Metode yang digunakan adalah metode deskriptif kuantitatif, adapun desain penelitian yang digunakan adalah cross-sectional survey design. Instrumen yang digunakan yaitu kuisioner/angket yang disebarkan kepada responden melalui kepala sekolah. Hasil penelitian menunjukkan bahwa Profil kompetensi pedagogik guru Taman Kanak-kanak tersertifikasi di Kecamatan Cicalengka Kabupaten Bandung hampir seluruhnya masuk pada kategori sangat baik dengan pemerolehan skor rata-rata 167,091. Dari hasil penelitian tersebut maka dapat disimpulkan bahwa hampir seluruh guru TK tersertifikasi yang berada di Kecamatan Cicalengka Kabupaten Bandung memiliki kompetensi pedagogik yang sangat baik.
\end{abstract}

Kata kunci: kompetensi pedagogik, guru taman kanak-kanak, sertifikasi guru

\footnotetext{
1 eka.fujilestari@yahoo.com

${ }^{2}$ Dosen Kampus UPI Cibiru

${ }^{3}$ Dosen Kampus UPI Cibiru
} 


\section{A. PENDAHULUAN}

Anak usia dini merupakan investasi yang sangat berharga bagi suatu bangsa. Karena anak usia dini merupakan penentu kemajuan dan keberhasilan bagi bangsanya. Oleh karena itu pendidikan anak usia dini dipandang sebagai hal yang sangat penting. Pandangan tersebut sudah disadari oleh setiap negara. Hal ini bisa dilihat dari perkembangan ilmu PAUD yang berkembang dengan begitu cepat.

Berbicara mengenai pendidikan, kita pasti akan berbicara mengenai proses pembelajarannya. Karena proses pembelajaran merupakan inti dari pendidikan itu sendiri. Proses pembelajaran merupakan usaha untuk mencapai tujuan pembelajaran yang telah ditentukan.

Dalam praktiknya, pada proses pembelajaran guru mempunyai peran yang sangat penting karena gurulah yang akan berhubungan langsung dengan anak. Dengan kata lain, guru mempunyai peranan yang sangat penting dalam meningkatkan kualitas pendidikan. Oleh sebab itu, guru perlu mengembangkan diri dan dikembangkan sebagai tenaga profesi yang memenuhi seluruh kompetensi guru yang ada, seperti kompetensi pedagogik, kompetensi profesionalisme, kompetensi sosial dan kompetensi kepribadian. Kompetensi yaitu sebuah kemampuan atau keahlian yang haras dimiliki oleh setiap guru sebagai sebuah profesi yang bisa diperoleh baik dari pendidikan formal, pelatihan, studi banding, maupun pengalaman mengajar yang selama ini sudah didapatkan.

Dalam meningkatkan kualitas guru, pemeritah sudah melakukan bermacammacam cara dan kegiatan yang beragam. Diantaranya yaitu adanya undang-undang yang mengatur mengenai berbagai macam hal yang bersangkutan dengan pendidikan khususnnya guru, yaitu UU No. 14 tahun 2005 yang mengatur mengenai Guru dan Dosen. Selain itu dibentuknya organisasi guru dalam tingkat nasional maupun daerah, dibentuknya kelompok kerja guru, adanya kegiatan diklat, pemberian beasiswa bagi guru yang melanjutkan kuliah, dan adanya sertifikasi.

Sertifikasi yaitu sebuah pemberian sertifikat pendidik atau bukti formal yang ditujukan untuk seorang guru atau dosen yang dinyatakan sebagai tenaga profesional. Dengan kata lain, idealnya guru yang telah mendapatkan sertifikat sebagai guru yang profesional atau sudah melewati proses sertifikasi memiliki kompetensi yang baik, baik itu kompetensi profesional, kompetensi sosial, kompetensi kepribadian maupun kompetensi pedagogiknya. Namun pada kenyataannya dilapangan masih ada guru yang sudah tersertifikasi belum memiliki kompetensi tersebut dengan baik.

Lokasi yang akan digunakan sebagai tempat penelitian ini adalah Kecamatan Cicalengka Kabupaten Bandung. Lokasi ini dipilih dengan berbagai pertimbangan dan alasan. Pertama, Kecamatan Cicalengka memiliki persentase terbesar keempat untuk guru TK tersertifikasi se-Kabupaten Bandung. Tepatnya Kecamatan Cicalengka menempati peringkat ke empat setelah Kecamatan Cileunyi, Kecamatan Margahayu, dan Kecamatan Rancaekek. Selain itu, dengan jumlah lembaga yang tidak sebanyak ketiga Kecamatan yang berada pada 
peringkat diatasnya yaitu 13 lembaga Kecamatan Cicalengka mampu menyumbangkan sebesar 1,87\% atau sebanyak 33 guru untuk 32,32\% atau 571 guru TK yang sudah tersertifikasi se-Kabupaten Bandung.

Selain itu, dari 33 guru/responden 60,61\% (20 orang) memiliki latar belakang yang sesuai dengan profesi yang dijalani yaitu SI jurusan PGPAUD dan yang lainnya SI PLS (Pendidikan Luar Sekolah) 15,15\% (5 orang), SI PAI 9,09\% (3 orang), SI PGSD 6,06\% (2 orang), Bahasa Indonesia 6,06\% (2 orang) dan SI Administrasi Pendidikan 3,03 \% (1 orang). Berdasarkan tersebut, dapat diketahui bahwa selurah guru tersertifikasi di Kecamatan Cicalengka memiliki latar belakang pendidikan, dan sebagian besar sesuai dengan profesinya.

Berdasarkan fakta yang telah dipaparkan diatas, peneliti ingin melihat gambaran kompetensi pedagogik guru TK tersertifikasi di Kecamatan Cicalengka Kabupaten Bandung. Penelitian yang dilakukan ini diharapkan bisa memberikan informasi yang bermanfaat kepada berbagai pihak, penelitian ini juga diharapkan bisa menjadi sumber data penelitian selanjutnya, khususnya yang berhubungan dengan kompetensi pedagogik guru TK. Rumusan masalah penelitian ini yaitu : "Bagaimana Profil Kompetensi Pedagogik Guru Taman Kanak-Kanak Tersertifikasi di Kecamatan Cicalengka Kabupaten Bandung".

Sejalan dengan itu, tujuan penelitian ini adalah untuk memperoleh gambaran yang jelas mengenai "Profil Kompetensi Pedagogik Guru Taman KanakKanak Tersertifikasi di Kecamatan Cicalengka Kabupaten Bandung".

\section{B. METODE}

Metode yang digunakan dalam penelitian ini adalah metode deskriptif kuantitatif. Yaitu sebuah metode penelitian yang berusaha menggambarkan dan menginterpretasikan objek sesuai fakta dengan menggunakan data statistik. Adapun desain penelitian yang digunakan adalah cross- sectional survey design. Desain ini digunakan apabila seorang peneliti ingin mengetahui sebuah isu yang bersifat kontemporer dengan pengumpulan data cukup satu kali dan tidak ada perlakuan terhadap responden.

Populasi penelitian ini yaitu seluruh guru taman kanak-kanak tersertifikasi yang berada di Kecamatan Cicalengka Kabupaten Bandung yang tersebar kedalam 11 lembaga dengan jumlah 33 guru yang semuanya merupakan seorang wanita. Selanjutnya yaitu penentuan sampel penelitian. Sampel penelitian yaitu sebagian subjek yang diambil dari populasi karena dirasa dapat mewakili populasi tersebut. Untuk menentukan sampel penelitian, penulis menggunakan teknik sampling jenuh. Dimana semua anggota populasi dijadikan sebagai sampel dalam penelitian ini, karena jumlah populasi dirasa kecil (Sugiyono, 2009). Hal ini sejalan dengan pernyataan yang diutarakan Sukardi dalam bukunya yaitu " ... untuk jumlah populasi kecil, sebaiknya seluruh populasi digunakan sebagai sumber pengambilan data" (2012, him. 55).

Kuesioner/angket dibuat dalam bentuk formulir yang berisi pertanyaanpertanyaan yang diajukan secara tertulis dan diberikan langsung kepada responden melalui Kepala Sekolah. Dari setiap pertanyaan terdapat lima pilihan jawaban, yang setiap point jawaban merupakan suatu skala penilaian. Skala penilaian yang digunakan adalah skala liken. "Skala liken digunakan untuk mengukur sikap, pendapat, dan presepsi seseorang atau sekelompok orang tentang fenomena sosial" (Sugiyono, 2009, him. 134). Sikap, pendapat, dan presepsi seseorang atau sekelompok orang tentang fenomena sosial yang dimaksud yaitu variabel yang telah 
ditentukan dalam penelitian ini yaitu mengenai kompetensi pedagogik guru TK. Adapun penilaian kuesioner menggunakan skala penilaian likert, yaitu sebagai berikut:

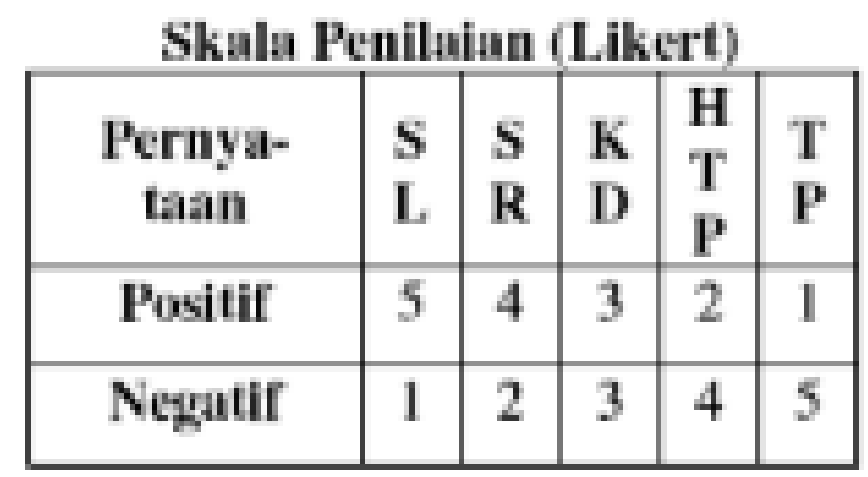

Keterangan:

SL : Selalu

SR : Sering

KD : Kadang-kadang

HTP : Hampir Tidak Pernah

TP : Tidak Pernah

Instrumen yang telah dibuat, diuji validitasnya. Uji validitas yang dilakukan yaitu uji validitas internal/rasional. Uji validitas ini terdiri dari validitas konstrak (disusun berdasarkan teori yang relevan) dan validitas konten (disusun berdasarkan rancangan / program yang telah ada). Uji internal ini dilakukan melalui konsultasi dengan para ahli (judgment ekspert) (Sugiyono, 2009).

Setelah itu, penulis selanjutnya melakukan uji coba keterpahaman instrumen penelitian. Uji keterpahaman ini dilakukan untuk mengetahui apakah instrumen yang dibuat dapat dipahami atau tidak. Uji ini dilakukan kepada 3 orang responden yang memiliki kriteria sama dengan sampel yang penulis pilih, yaitu guru TK yang sudah tersertifikasi.

Adapun tahapan analisis data yang dilakukan oleh penulis mengacu pada teknik pengolahan data yang dipaparkan oleh Margono (dalam Zuriah, 2007) dan Haristi (2015) diantaranya yaitu :

\section{1. $\quad$ Editing}

Pada tahap editing, data yang sudah terkumpul melalui daftar pertanyaan kuesioner dibaca kembali untuk mengetahui apakah ada hal-hal yang masih meragukan dari jawaban responden yang bertujuan untuk meningkatkan kualitas data dan menghilangkan keraguan data.

\section{Koding}

Pada tahap ini, masing-masing data yang telah terkumpul diberikan sebuah kode yang sesuai dengan kriteria yang sama. Kode yang diberikan dalam analisis kuantitatif adalah sebuah angka yang tidak lain angka tersebut merupakan skor atau skala penilaian.

\section{Tabulasi Data}

Pada tahap ini, data yang telah diberi kode pada tahap sebelumnya kemudian dimasukan ke dalam bentuk tabel atau daftar agar memudahkan pengamatan dan proses analisis.

4. Analisis data 
Data yang sudah berhasil dikumpulkan akan dianalisis dengan metode analisis kuantitatif.

Penggunaan statistika dalam analisis kuantitatif sangat diperlukan, statistika yang digunakan dalam penelitian ini adalah statistika deskriptif. Menurut Sugiyono, statistik deskriptif adalah "statistik yang digunakan untuk menganalisis data dengan cara mendeskripsikan atau menggambarkan data yang telah terkumpul sebagaimana adanya tanpa bermaksud membuat kesimpulan yang berlaku untuk umum atau generalisasi" (2009, him. 207-208).

Data hasil penelitian atas variabel kompetensi pedagogik guru TK tersertifikasi selanjutnya dikategorikan menurut 5 tingkatan, yaitu sangat baik, baik, cukup, kurang baik dan tidak baik. Hasil penentuan kriteria tersebut melalui sebuah perhitungan yang mengacu pada paparan Fitriana (2013) dalam skripsinya yaitu :

a. Menentukan skor tertinggi dengan mengalikan nilai paling tinggi dengan jumlah soal;

b. Menentukan skor terendah dengan mengalikan nilai paling kecil dengan jumlah soal;

c. Menentukan rentang data dengan mengurangi skor tertinggi dengan skor terendah;

d. Menentukan panjang kelas interval, dengan membagi rentang data dengan banyaknya kriteria;

e. Mengelompokkan interval nilai dan melengkapinya dengan kategori kualitatif.

Selain deskripsi diatas, dilakukan pula analisis ketercapaian skor. Analisis ini dilakukan untuk mengidentifikasi tinggi rendahnya skor responden atas variabel penelitian melalui perhitungan persentase ketercapaian skor total dari skor ideal. Adapun rumus yang digunakan mengacu pada paparan

Indartini (2012), rumus tersebut yaitu :

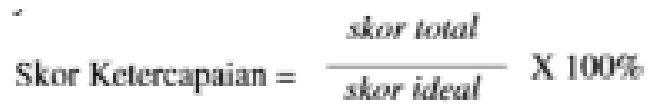

Skor total $=$ Skor total yang diraih

Skor ideal $=$ Jumlah soal $\mathrm{x}$ bobot maksimal $\mathrm{x}$ jumlah responden

Setelah melalui proses pengolahan data, kemudian dilakukan penafsiran data yang merupakan kesimpulan dari hasil penelitian. Adapun untuk penafsiran data peneliti akan menggunakan kriteria sebagai berikut, yaitu :
a. $0 \%$ : Ditafsirkan tidak ada
b. $\quad 1 \%-24 \%$ : Ditafsirkan sebagian kecil
c. $25 \%-49 \%$ : Ditafsirkan hampir setengahnya
d. $50 \%$ : Ditafsirkan setengahnya
e. $51 \%-74 \%$ : Ditafsirkan sebagian besar
f. $\quad 75 \%-99 \%$ : Ditafsirkan hampir seluruhnya
g. $\quad 100 \% \quad$ : Ditafsirkan seluruhnya

\section{Interpretasi Data}

Setelah data dianalisis dengan teknik statistik, hasilnya diinterpretasikan secara deskriptif, dianalisis, dan kemudian ditarik kesimpulan. 


\section{PEMBAHASAN}

Angket/kuisioner yang telah terkumpul dihitung berdasarkan bobot nilai yang sudah ditentukan, sehingga didapat skor-skor mentah sesuai alternatif jawaban yang ada. Skor-skor mentah tersebut kemudian di klasifikasikan berdasarkan norma yang telah diuraikan pada bagian pembahasan mengenai metode penelitian. Agar hasil penelitian dapat terlihat jelas, maka data yang telah didapat akan disajikan kedalam sebuah gambar.

Data hasil penelitian terkait kompetensi pedagogik guru taman kanak-kanak tersertifikasi di Kecamatan Cicalengka Kabupaten Bandung dikategorisasikan menurut 5 tingkatan, yaitu tidak baik, kurang baik, cukup, baik dan sangat baik. Hasil penentuan kriteria adalah sebagaimana ditunjukan tabel berikut:

\section{Kategorisasi Kompetensi Pedagogik Guru TK Tersertifikasi di Kecamatan Cicalengka}

\begin{tabular}{|l|c|c|}
\hline N O & INTERVAL & KATEGORI \\
\hline 1 & $36-65$ & Tidak Baik \\
\hline 2 & $66-95$ & Kurang Baik \\
\hline 3 & $96-125$ & Cukup \\
\hline 4 & $126-155$ & Baik \\
\hline 5 & $156-185$ & Sangat Baik \\
\hline
\end{tabular}

Hasil Penelitian yang dilakukan terkait kompetensi pedagogik guru taman kanak-kanak tersertifikasi di Kecamatan Cicalengka Kabupaten Bandung adalah sebagai berikut:

Skor Total Kompetensi Pedagogik

Guru TK yang Tersertifikasi di Kecamatan Cicalengka Kabupaten Bandung

\begin{tabular}{|l|l|r|c|}
\hline No & Nama & Total & Keterangan \\
\hline 1 & SJ & 181 & Sangat Baik \\
\hline 2 & NA & 168 & Sangat Baik \\
\hline 3 & DT & 168 & Sangat Baik \\
\hline 4 & FY & 167 & Sangat Baik \\
\hline 5 & CS & 157 & Sangat Baik \\
\hline 6 & SM & 168 & Sangat Baik \\
\hline 7 & AIM & 154 & Baik \\
\hline 8 & AJ & 170 & Sangat Baik \\
\hline 9 & FS & 155 & Baik \\
\hline 10 & CN & 171 & Sangat Baik \\
\hline 11 & ESR & 162 & Sangat Baik \\
\hline 12 & n & 162 & Sangat Baik \\
\hline 13 & ESA & 174 & Sangat Baik \\
\hline 14 & SM & 171 & Sangat Baik \\
\hline 15 & NHY & 177 & Sangat Baik \\
\hline 16 & AH & 175 & Sangat Baik \\
\hline 17 & AN & 175 & Sangat Baik \\
\hline
\end{tabular}




\begin{tabular}{|c|c|c|c|}
\hline No & Nama & Total & Keterangan \\
\hline 18 & NR & 176 & Sangat Baik \\
\hline 19 & SSL & 178 & Sangat Baik \\
\hline 20 & EN & 176 & Sangat Baik \\
\hline 21 & SLH & 172 & Sangat Baik \\
\hline 22 & NN & 172 & Sangat Baik \\
\hline 23 & LYH & 178 & Sangat Baik \\
\hline 24 & NSN & 145 & Baik \\
\hline 25 & ETR & 133 & Baik \\
\hline 26 & RA & 170 & Sangat Baik \\
\hline 27 & $\mathrm{SH}$ & 181 & Sangat Baik \\
\hline 28 & AN & 166 & Sangat Baik \\
\hline 29 & TT & 166 & Sangat Baik \\
\hline 30 & $\mathrm{HH}$ & 164 & Sangat Baik \\
\hline 31 & HLD & 164 & Sangat Baik \\
\hline 32 & II & 154 & Baik \\
\hline 33 & UJ & 163 & Sangat Baik \\
\hline \multicolumn{2}{|c|}{ Rata-rata } & 167,091 & Sangat Baik \\
\hline \multicolumn{2}{|c|}{ Sumber: Hasil } & \multicolumn{2}{|c|}{ Pengolahan Angket } \\
\hline
\end{tabular}

Dari 33 guru yang menjadi sampel dalam penelitian ini, sebanyak 28 guru atau sebesar $84,85 \%$ dapat dikatakan memiliki kompetensi pedagogik guru TK yang sangat baik. Dan 5 guru atau sebesar $15,15 \%$ dari banyaknya responden memiliki kompetensi pedagogik guru TK yang baik. Sedangkan untuk kategori cukup, kurang baik dan tidak baik memiliki persentase $0 \%$, yang artinya tidak ada satupun responden yang masuk kedalam 3 kategori ini. Berdasarkan tabel diatas, terlihat juga bahwa secara keseluruhan kompetensi pedagogik guru TK tersertifikasi di Kecamatan Cicalengka Kabupaten Bandung mencapai rata-rata sebesar 167,091 dengan skor ketercapaian 90,32\% dan termasuk kedalam kategori sangat baik. Dengan kata lain, hampir seluruh guru TK yang sudah tersertifikasi di Kecamatan Cicalengka Kabupaten Bandung memiliki kompetensi pedagogik guru TK yang sangat baik.

Gambarankompetensi pedagogik guru TK tersertifikasi diatas dapat divisualisasikan melalui gambar berikut:

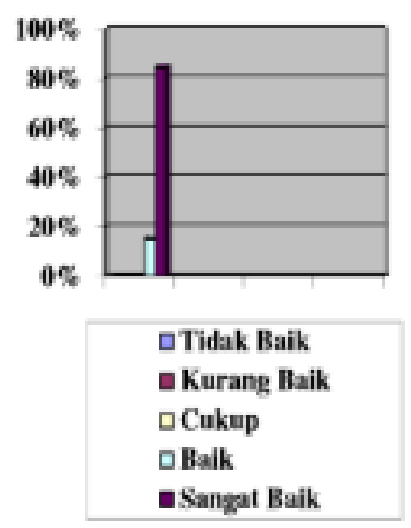




\section{Gambaran Kompetensi Pedagogik Guru TK Tersertifikasi di Kecamatan Cicalengka Kabupaten Bandung}

Setelah hasil penelitian didapat, maka hal yang harus dilakukan selanjutnya adalah memaparkan pembahasan dari hasil penelitian. Dalam penelitian ini, pembahasan dilakukan dengan tujuan untuk menerangkan dan menginterprestasikan hasil penelitian dengan rumusan masalah serta tujuan penelitian, yaitu : Profil kompetensi pedagogik guru Taman Kanak-kanak tersertifikasi di Kecamatan Cicalengka Kabupaten Bandung.

Data variabel penelitian yaitu kompetensi pedagogik guru TK tersertifikasi telah dianalisis dengan menggunakan teknik yang telah dijelaskan sebelumnya. Penilaian terhadap variabel penelitian ini mengacu pada peraturan menteri pendidikan dan kebudayaan Republik Indonesia No. 137 tahun 2014 tentang standar nasional pendidikan anak usia dini (standar pendidik dan tenaga kependidikan), berikut adalah pembahasannya.

Sanjaya (2012) menyatakan bahwa pembelajaran adalah sebuah sistem, maka dalam pelaksanaan pembelajaran haruslah memiliki komponen yang berproses sesuai dengan fungsinya sehingga tujuan pembelajaran yang sudah ditentukan dapat tercapai dengan optimal. Dalam pelaksanaan pembelajaran tersebut guru merupakan salah satu komponennya, jadi guru mempunyai peran yang penting dalam mencapai keberhasilan pembelajaran.

Selanjutnya dijelaskan dalam UU No. 14 Tahun 2005 Tentang Guru dan Dosen Bab 1 Pasal 1 bahwa "Guru adalah pendidik profesional dengan tugas utama mendidik, mengajar, membimhing,

mengarahkan, melatih, menilai, dan mengevaluasi peserta didik pada pendidikan anak usia dini jalur pendidikan formal, pendidikan dasar, dan pendidikan menengah" (2005, him. 2). Dalam pelaksanaan tugas tersebut, guru harus memiliki kompetensi atau kemampuan yang baik. Kompetensi tersebut diantaranya yaitu kompetensi pedagogik, kompetensi profesional, kompetensi sosial, dan kompetensi kepribadian. Walaupun dalam pelaksanaannya keempat kompetensi tersebut saling berkaitan, tapi dalam penelitian ini penulis memfokuskan pada kompetensi pedagogik saja.

Dalam Standar Nasional Pendidikan, Pasal 28 ayat (3) butir a bahwa kompetensi pedagogik adalah kemampuan mengelola pembelajaran peserta didik yang meliputi pemahaman terhadap peserta didik, perancangan dan pelaksanaan pembelajaran, evaluasi hasil belajar, dan pengembangan peserta didik untuk mengaktualisasikan berbagai potensi yang dimilikinya (2005). Dari hasil penelitian yang telah dilakukan penulis, secara keseluruhan kompetensi pedagogik guru TK tersertifikasi di Kecamatan Cicalengka Kabupaten Bandung mencapai skor rata-rata sebesar 167,091 dan skor ketercapaian 90,32\%. Dengan kata lain, hampir seluruh guru TK yang sudah tersertifikasi di Kecamatan Cicalengka Kabupaten Bandung memiliki kompetensi pedagogik guru TK yang sangat baik. Dari hasil penelitian 
tersebut penulis dapat menarik kesimpulan bahwa guru TK tersertifikasi sudah bisa mempraktekan ketentuan-ketentuan kompetensi pedagogik dengan baik. Ketentuan kompetensi pedagogik tersebut dipaparkan dalam Peraturan Menteri Pendidikan dan Kebudayaan Republik Indonesia No. 137 Tahun 2014 Tentang Standar Nasional Pendidikan Anak Usia Dini (Standar Pendidik dan Tenaga Kependidikan).

\section{PENUTUP}

Pemaparan kesimpulan ini mengacu pada pokok permasalahan yaitu profil kompetensi pedagogik guru TK tersertifikasi di Kecamatan Cicalengka Kabupaten Bandung. Kesimpulan ini kemudian bisa dijadikan sebagai rekomendasi bagi semua pihak yang berkepentingan. Berikut pemaparan kesimpulan dan implikasi serta rekomendasi penelitian yang dilakukan penulis.

Atas dasar teori-teori yang relevan, penulis telah mencari dan menganalisis data penelitian, kemudian penulis dapat menarik kesimpulan bahwa kompetensi pedagogik guru Taman Kanak-kanak tersertifikasi di Kecamatan Cicalengka Kabupaten Bandung hampir seluruhnya masuk pada kategori sangat baik dengan pemerolehan skor rata-rata 167,091 ;

Selanjutnya berdasarkan kesimpulan yang telah dipaparkan diatas, sebagai tindak lanjut dari penelitian ini akan dipaparkan beberapa hal yang penulis rekomendasikan. Rekomendasi penulis ini diharapkan dapat menjadi masukan bagi pihak-pihak yang dirasakan mempunyai kepentingan terhadap penelitian ini. Adapun rekomendasi tersebut diantaranya yaitu :

1. Bagi Guru

Memiliki kompetensi pedagogik yang sangat baik merupakan salah satu prestasi bagi guru dalam melaksanakan profesinya. Hal ini patut dipertahankan demi meningkatkan kualitas pendidikan. Selain itu, para guru yang sudah memiliki kompetensi pedagogik yang sangat baik harus menjadi panutan dan memberikan motivasi untuk guru yang lainnya

2. Bagi Lembaga Sekolah

Walaupun sebagian besar atau hampir seluruh guru TK tersertifikasi yang mengabdi di lembaga TK Kecamatan Cicalengka telah memiliki kompetensi pedagogik yang sangat baik, namun lembaga masih tetap harus mengembangkan semua kompetensi yang harus dimiliki oleh seorang guru TK, baik yang sudah tersertifikasi maupun yang belum tersertifikasi.

3. Bagi Peneliti Lain

Bagi peneliti lain yang ingin meneliti mengenai kompetensi pedagogik bisa memfokuskan pada salah satu variabel atau indikator yang terkandung dalam Peraturan Menteri Pendidikan dan Kebudayaan Republik Indonesia No. 137 Tahun 2014 Tentang Standar Nasional Pendidikan Anak Usia Dini (Standar Pendidik dan Tenaga Kependidikan). Selain itu bisa juga menambah instrumen yang digunakan, seperti dengan menggunakan observasi dan wawancara.

\section{DAFTAR PUSTAKA}

Fitriana, A. (2013). Upaya Pengembangan Kompetensi Profesional Guru Taman Kanak-kanak di Kecamatan Bantul Kabupaten Bantul. (Skripsi). Sekolah Sarjana Pendidikan Strata 1, universitas Negeri

Haristi, R. (2015). Minat Siswa Kelas XII Kecamatan Sukasari Kota Bandung 
Terhadap Program Studi SI PGPAUD FIP UPI. (Skripsi). Sekolah Sarjana Pendidikan Strata 1, Universitas Pendidikan Indonesia, Bandung.

Indartini, C. S. (2012). Profil Kompetensi Guru Taman Kanak-kanak Tersertifikasi Yayasan Salib Suci Bandung. (Skripsi). Sekolah Sarjana Pendidikan, Universitas Pendidikan Indonesia, Bandung.

Presiden Republik Indonesia. (2005). Undang-Undang Republik Indonesia Nomor 14 Tahun 2005 Tentang Guru dan Dos en. Jakarta : Presiden Republik Indonesia.

Peraturan Menteri Pendidikan dan Kebudayaan Republik Indonesia No. 146 Tahun 2014. (2014). Kurikulum 2013 Pendidikan Anak Usia Dini. Jakarta: Mendikbud.

Sugiyono.(2009). Metode Penelitian Pendidikan : Pendekatan Kuantitatif, kualitatif dan R\&D. Bandung : Alfabeta.

Sukardi. (2012). Metodologi Penelitian Pendidikan - Kompetensi dan Praktiknya. Jakarta : PT. Bumi Aksara. Yogyakarta, Yogyakarta.

Sanjaya, W. (2012). Perencanaan dan Desain Sistem Pembelajaran. Jakarta : Kencana Prenada Media Group.

Zuriah, N. (2007). Metodologi Penelitian Sosial dan Pendidikan : Teori - Aplikasi. Jakarta : PT. Bumi Aksara. 